\title{
Reduced Pollination Efficiency Compromises Some Physicochemical Qualities in Gac (Momordica cochinchinensis Spreng.) Fruit
}

\author{
Xuan T. Tran ${ }^{1,2}$, Sophie E. Parks $1,3, * \mathbb{D}$, Minh H. Nguyen ${ }^{1,4}$ (D) and Paul D. Roach ${ }^{1}$ \\ 1 School of Environmental and Life Sciences, University of Newcastle, Ourimbah, NSW 2258, Australia; \\ thixuan.tran@uon.edu.au (X.T.T.); minh.nguyen@newcastle.edu.au (M.H.N.); \\ paul.roach@newcastle.edu.au (P.D.R.) \\ 2 The North Vietnam College of Agriculture and Rural Development, Hanoi 13400, Vietnam \\ 3 Central Coast Primary Industries Centre, NSW Department Primary Industries, \\ Ourimbah, NSW 2258, Australia \\ 4 School of Science and Health, University of Western Sydney, Penrith, NSW 2751, Australia \\ * Correspondence: sophie.parks@dpi.nsw.gov.au; Tel.: +61-243481914; Fax: +61-243481910
}

Citation: Tran, X.T.; Parks, S.E.; Nguyen, M.H.; Roach, P.D. Reduced Pollination Efficiency Compromises Some Physicochemical Qualities in Gac (Momordica cochinchinensis Spreng.) Fruit. Agronomy 2021, 11, 190. https://doi.org/10.3390/ agronomy11010190

Received: 11 December 2020

Accepted: 14 January 2021

Published: 19 January 2021

Publisher's Note: MDPI stays neutral with regard to jurisdictional claims in published maps and institutional affiliations.

Copyright: (c) 2021 by the authors. Licensee MDPI, Basel, Switzerland. This article is an open access article distributed under the terms and conditions of the Creative Commons Attribution (CC BY) license (https:// creativecommons.org/licenses/by/ $4.0 /)$.

\begin{abstract}
Gac is valued for the nutritious aril surrounding its seed. When pollinators are limited or when flower sex expression is female-biased, hand pollination is necessary. Here, female flowers were hand pollinated with male flowers or pollen stored for up to 84 days at 4 or $-20{ }^{\circ} \mathrm{C}$, and fruit set and some qualities of mature fruit were evaluated. Cool storage reduced pollen viability (germinability and pollen tube length) and compromised fruit set (10-87\%) compared with fresh pollen (97\%). Fruit weight was also reduced at least by $8 \%$, and oil concentration in aril by $40 \%$. However, the lycopene and $\beta$-carotene concentrations in aril were largely uncompromised, and some fruits were of a marketable weight $(>1.2 \mathrm{~kg})$ and quality. Cool storage is a low-cost method for the short-term storage of Gac pollen. However, methods for drying pollen to an inactive state need investigation for a storage protocol, and for improvements in fruit set and fruit physicochemical qualities using hand pollination.
\end{abstract}

Keywords: in vitro test; in vivo test; fatty acids; pollen viability; recalcitrant pollen; orthodox pollen

\section{Introduction}

The Gac plant (Momordica cochinchinensis Spreng.) is a dioecious species of the Cucurbitaceae family [1], and the fruit is traditionally used for its culinary and medicinal properties in Vietnam, where it grows naturally. The aril surrounding the seed contains bioactive products including lycopene, $\beta$-carotene, fatty acids, vitamin $E$, flavonoids and polyphenol compounds [2-5], and the oil contains a high concentration of oleic acid (32-34\% of total fatty acids) [6]. It is the aril that is harvested for food preparation and for processing into commercial additives and health products [5]. The yield of aril from the Gac fruit depends on fruit size, with smaller fruit having a lower proportion of aril than larger fruits [7]. The total number of Gac fruits produced per plant has been shown to influence fruit size, with the mean weight of all fruits reduced as the total fruit number per plant, and thus sink demand, is increased [8]. However, as demonstrated in other crops, fruit size and fruit quality can be affected by pollination processes. For example, the tropical fruits sugar apple and atemoya had reduced fruit size when their flowers were hand pollinated with pollen stored in a refrigerator for longer than $18 \mathrm{~h}$ [9], and the dry matter content of apple, which relates to consumer preferences, was increased when supplementary pollen was applied to flowers [10].

Gac is grown as a trellised crop and is open pollinated by insects in traditional growing systems [8,9]. However, the production of Gac under crop covers or in a greenhouse is a barrier to insects, and hand pollination is required for fruit set $[7,11]$. Greenhouse 
cultivation has the advantage of crop production during temperate winters when Gac is otherwise dormant [7]. Hand pollination can also be required when the pollen resource is limited, which can be a problem for cucurbit crops when pollinators are not present to transport pollen or when sex-expression is variable and biases the production of male or female flowers [12]. In one example, in several expansive plots within a Cucurbita maxima crop, only female flowers were observed [12]. Gac crops are not excluded from variable sex expression, having been observed with male flowers appearing first [7] or female flowers appearing first in the season [13]. Thus, the need for pollen collection for the purposes of manual pollination may arise in Gac production for several reasons.

Between the maturation of the Gac pollen grain in the anther and its journey to a distant stigma prior to fertilization, pollen has the potential to lose viability if the prevailing conditions of its immediate environment, such as temperature and humidity, are not ideal. Poor conditions can occur, for example, in the crop environment itself, or in the process of pollen collection and use in hand pollination. Given the value placed on the nutritional qualities of the Gac aril, it is pertinent to understand the potential impact that pollen viability may have on fruit quality and to explore the potential for the simple storage of pollen, for when it may be needed for later hand pollination. Our research objective was to determine if Gac pollen can be collected and simply stored and used to pollinate flowers and produce high-quality fruit. Initially, the viability of fresh pollen, in terms of germinability as proportion germinated and pollen tube length, and its moisture content, were observed in ambient conditions over time. The viability of fresh pollen compared with cool-stored $\left(4\right.$ and $-20^{\circ} \mathrm{C}$ ) pollen was then assessed in vitro. In vivo assessment of fresh pollen and cool-stored pollen, which encompassed a range of viability levels, involved using pollen to pollinate flowers, with resulting fruit assessed for the physicochemical qualities of fruit. These were weight including aril weight, the number of developed and under-developed seeds, and in aril, the total soluble solids (TSS), and the oil and carotenoid concentrations.

\section{Materials and Methods}

\subsection{Crop Production}

A Gac crop was produced in four climate-controlled greenhouses located at the NSW Department of Primary Industries Research Station, Ourimbah, New South Wales, Australia $\left(151^{\circ} 22^{\prime} \mathrm{E}, 33^{\circ} 21^{\prime} \mathrm{S}\right)$ with the temperature and relative humidity $(\mathrm{RH})$ maintained between 18 and $25{ }^{\circ} \mathrm{C}$ and 60 and $80 \%$, respectively. A total of 44 plants ( 24 female and 20 male) were grown in bags of coir substrate and supplied hydroponically with water and nutrients through drippers (February 2013). Gac pollen was collected from the male flowers for the storage studies. The female flowers were pollinated with fresh and stored pollen for the in vivo test.

\subsection{Pollen Collection and Storage Treatments}

Approximately 40-50 male flowers were collected, approximately two hours after anthesis, and stored daily (7 days per week) for 3 months to supply the blooming female flowers at anthesis with pollen. The petals of the male flowers were removed, and anthers were placed on metal trays in the laboratory at room temperature $\left(21 \pm 1^{\circ} \mathrm{C}, \mathrm{RH} 60 \%\right)$. The fresh pollen was dried for $1 \mathrm{~h}$ at room temperature and collected in vials, with each vial containing $1.0 \mathrm{~g}$ of pollen.

\subsubsection{Ambient Storage}

Vials were stored at room temperature $\left(21 \pm 1^{\circ} \mathrm{C}, \mathrm{RH} 60 \%\right)$ for up to 9 days. The pollen stored at room temperature was also observed for moisture loss of three replicates, daily. The moisture content of pollen was approximately 13-14\% prior to storage. Pollen moisture content was measured as described by Hong et al. [14] and expressed on a \% wet basis. Five separate samples were assessed daily for nine days. 


\subsubsection{Cool Storage}

Vials were stored in one of three combined refrigerator/freezer compartments at $4{ }^{\circ} \mathrm{C}$ or $-20^{\circ} \mathrm{C}$ for up to 84 days. Three separate samples were pooled within each temperature treatment prior to in vitro assessment for each storage time $(7,14,28,56$ and 84 days). For in vivo assessment, individual pollen samples were taken out of the refrigerator or freezer and left at room temperature for $1 \mathrm{~h}$ before use.

\subsection{In Vitro Pollen Viability Assessments}

For the in vitro assessments, germination and tube length of pollen were measured using methods specifically developed for Gac [8]. For all assessments following storage, pollen was cultured on five $9 \mathrm{~cm}$ petri dishes with $15 \mathrm{~mL}$ of agar medium containing $15 \%$ sucrose, $1 \%$ agar, $0.01 \% \mathrm{H}_{3} \mathrm{BO}_{3}, 0.01 \% \mathrm{KNO}_{3}, 250 \mathrm{mgL}^{-1} \mathrm{MgSO}_{4} 7 \mathrm{H}_{2} \mathrm{O}$ and $700 \mathrm{mgL}^{-1} \mathrm{Ca}$ $\left(\mathrm{NO}_{3}\right)_{2} 4 \mathrm{H}_{2} \mathrm{O}$. The $\mathrm{pH}$ of the medium was adjusted to 6.0 before autoclaving. These dishes were placed in the dark in an incubator at a temperature of $35^{\circ} \mathrm{C}$ for $24 \mathrm{~h}$. Pollen viability was determined through the observation of grains using a microscope with $40 \times$ ocular lenses. The four fields of view per petri dish were assessed and contained approximately 50-200 pollen grains. Counts from the four fields of view were added to obtain totals. Pollen grains were considered germinated when a pollen tube was observed, being at least the length of the diameter of the pollen grain. Pollen tube lengths were measured using an ocular micrometer attached to the microscope on at least 20 pollen grains. Figure 1 is a microscopic image of Gac pollen and shows viable pollen with a protruding pollen tube, typical of those used to measure pollen tube length.

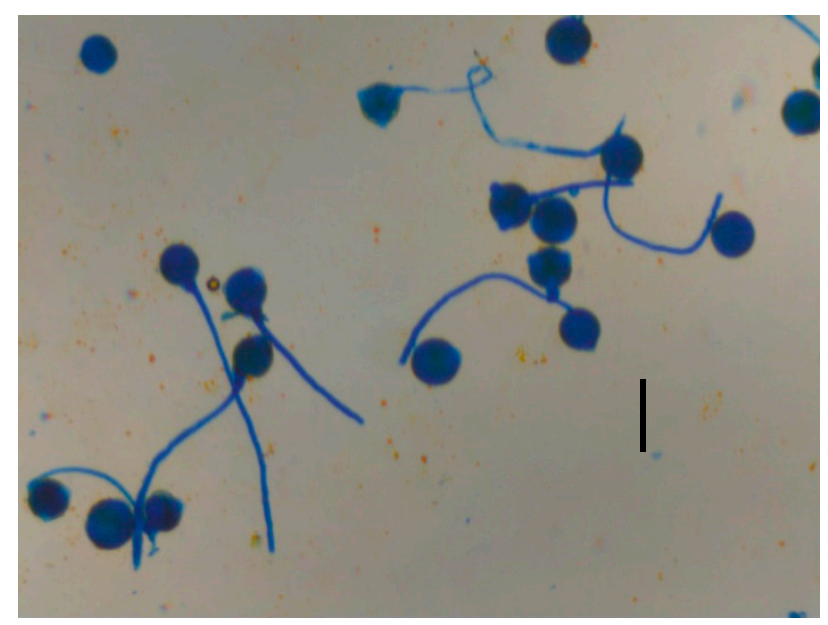

Figure 1. Germinated Gac pollen showing pollen tube growth (stained with aniline blue, bar represents $100 \mu \mathrm{m})$.

\subsection{In Vivo Pollen Viability Assessments}

Samples of pollen stored in individual vials at either $4{ }^{\circ} \mathrm{C}(60 \% \mathrm{RH})$ or $-20{ }^{\circ} \mathrm{C}$ ( $70 \% \mathrm{RH}$ ) for either 14 days, 28 days, 56 days or 84 days were randomly allocated to plots and pollinated in sequential order of female flower opening. Each treatment contained three replicate plots of ten female flowers. The female flowers were pollinated on the first day of opening at 9 a.m. Approximately $0.05 \mathrm{~g}$ of pollen (the equivalent weight of pollen from one fresh male flower) from each treatment was rubbed onto the stigma of the female flower with a brush. The control flower plots were pollinated directly with fresh pollen by placing anthers onto the stigma of female flowers. The pollination date was labelled on each pollinated flower and Gac fruits were harvested mature at 14 weeks after pollination. The number of fruit set per plot was assessed four weeks after pollinating when the fruitlets had started to develop. 


\subsection{Fruit Physiological Properties}

Fruit weight, including the weight of the seed aril, was measured using an electronic balance (Kern \& Sohn, Balingen, Germany, $\pm 0.01 \mathrm{~g}$ ). The proportion of aril weight as a function of fruit weight was calculated. Seed was separated from the aril and sorted into fully developed, approximately $4 \mathrm{~g}$ and dark brown in colour, and under-developed seed, less than $4 \mathrm{~g}$ and white in colour, and counted.

\subsection{Chemical Properties of the Aril}

\subsubsection{Total Soluble Solids (TSS) of the Aril}

The combined aril from under-developed and fully developed seeds was blended in an electric food processer. The aril juice was then filtered using a cloth to determine total soluble solids (TSS). TSS was measured using a digital refractometer Atago 3810 Pal-1 (Atago Co. Ltd., Tokyo, Japan) with $0.3 \mathrm{~mL}$ volume per sample and expressed as Brix.

\subsubsection{Determination of Total Oil and Carotenoid Concentrations}

The methods of Kha et al. [15] were employed to analyse the carotenoid contents ( $\beta$-carotene and lycopene) and total oil content of Gac fruit aril, combined from underdeveloped and fully developed seeds. A high-performance liquid chromatography (HPLC) system was set up with an Agilent 1200 HPLC and Shimadzu LC-10AD HPLC equipped with detector of a Luna C18 $(100 \times 46 \mathrm{~mm})$ coupled to a Jupiter C18 $(250 \times 46 \mathrm{~mm})$ column (Phenomenex, Lane Cove, NSW, Australia). The mobile phase consisted of acetonitrile $(\mathrm{ACN})$, dichloromethane $(\mathrm{DCM})$ and methanol $(\mathrm{MeOH})(5: 4: 1, v / v / v)$. The injection volume was $20 \mu \mathrm{L}$, the flow rate was $1.0 \mathrm{~mL} \mathrm{~min}^{-1}$, and detection was at $450 \mathrm{~nm}$. The $\beta$ carotene and lycopene were quantified based on the retention times of peaks and compared with authentic standards (Sigma-Aldrich, Castle Hill, NSW, Australia), and their content was expressed as $\mathrm{mg} \mathrm{g}^{-1}$ of fresh aril weight (FW). The serial extraction Soxhlet apparatus was used to extract the oil from Gac aril. A total of $3 \mathrm{~g}$ of the dried aril was placed in a cellulose thimble, which was inserted into the extraction system with $300 \mathrm{~mL}$ of boiling hexane until the sample was colourless. The extracted aril sample was dried at $70{ }^{\circ} \mathrm{C}$ in a vacuum oven (Vord-46OD; Australasian Scientific Marketing Group) until a constant weight. The oil content was expressed as a percentage of dry weight $\left(\mathrm{g} \mathrm{g}^{-1} \mathrm{dry}\right.$ weight, DW).

\subsection{Statistical Analysis}

For pollen stored in ambient conditions for 9 days, a generalised linear model (GLM) and logistic regression fitted storage time as a variate to the germination data with binomial error distribution and logit link function (dispersion parameter 6.33 from residual deviance, $p<0.001$ ). A linear regression fitted storage time as a variate to pollen tube length $(83.5 \%$ variance accounted for, $p<0.001)$ and pollen moisture content $(93.9 \%$ variance accounted for, $p<0.001)$. For the viability of cold-stored pollen, the three separate samples stored at either $4{ }^{\circ} \mathrm{C}$ or $-20^{\circ} \mathrm{C}$ were pooled prior to viability assessments and, therefore, the experimental units (5 petri dishes) were treated as pseudo replicates. Data are summarized as means $( \pm \mathrm{SD})$ and means are not separated, as appropriate. For the in vivo assessment, stored pollen was used to pollinate flowers and resultant fruits were assessed, and the experimental layout was a completely randomized design with three replicates. The treatment structure was a $2 \times 4$ factorial with a control. Analysis of variance was conducted with the factors of storage temperature $\left(4^{\circ} \mathrm{C}\right.$ or $\left.-20^{\circ} \mathrm{C}\right)$ and storage time $(14,28,56,84$ days), with fresh pollen as the control. Treatment means are separated by least significant difference (LSD). Binomial data (aril proportion of fruit weight and developed seed number as a proportion of total seeds) yielded the same results as transformed data, so untransformed data are presented. Data were analysed using GenStat software [16]. 


\section{Results}

\subsection{The Viability of Pollen Stored under Ambient Conditions}

Fresh pollen stored at $21{ }^{\circ} \mathrm{C}(60 \% \mathrm{RH})$ for up to 9 days generally declined in viability over time, as indicated by reductions in germination and pollen tube length (Figure 2a,b). The pollen germination and pollen tube length responses to age were both significant regressions $(p<0.001)$. The decline in viability was associated with a significant decline in moisture content $(p<0.001)$. By day 9 , the pollen had lost $50 \%$ of its initial moisture content (Figure 2c).
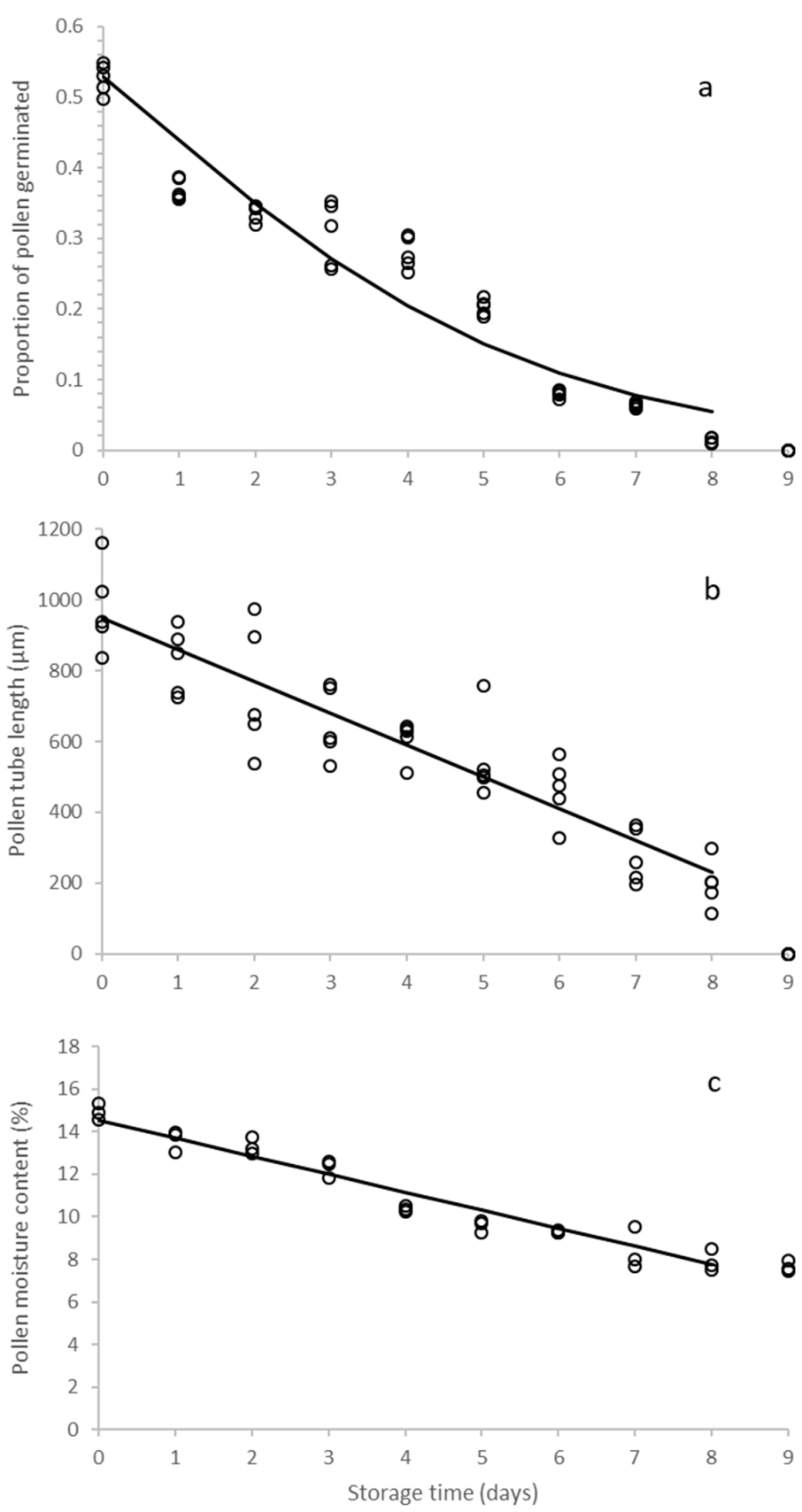

Figure 2. Response of germinability and moisture content of fresh pollen in ambient conditions $\left(21^{\circ} \mathrm{C}\right.$, $60 \% \mathrm{RH}$ ) for up to 9 days: proportion of pollen germinated (a), mean pollen tube length (b) and moisture content (c). Open circles are mean values in $(\mathbf{a})$ and $(\mathbf{b})(n=4)$ and raw values in c. Lines are fitted regressions: $\mathrm{y}=0.005 \mathrm{x}^{2}-0.1038 \mathrm{x}+0.5334(\mathbf{a}),-90.065 \mathrm{x}+949.43(\mathbf{b}),-0.8457 \mathrm{x}+14.543(\mathbf{c})$. 


\subsection{The Viability of Cold-Stored Pollen}

The viability of Gac pollen stored at $4{ }^{\circ} \mathrm{C}$ and $-20{ }^{\circ} \mathrm{C}$ for up to 84 days is presented in Figure 3. These data highlight the general decline in the germinability of pollen and the length of pollen tubes as the time spent in cool storage increased $\left(4{ }^{\circ} \mathrm{C}\right.$ or $\left.-20^{\circ} \mathrm{C}\right)$. The potential for the short-term cool storage of Gac pollen is demonstrated here beyond that shown for ambient storage (Figure 3).

․․-20 degrees celsius
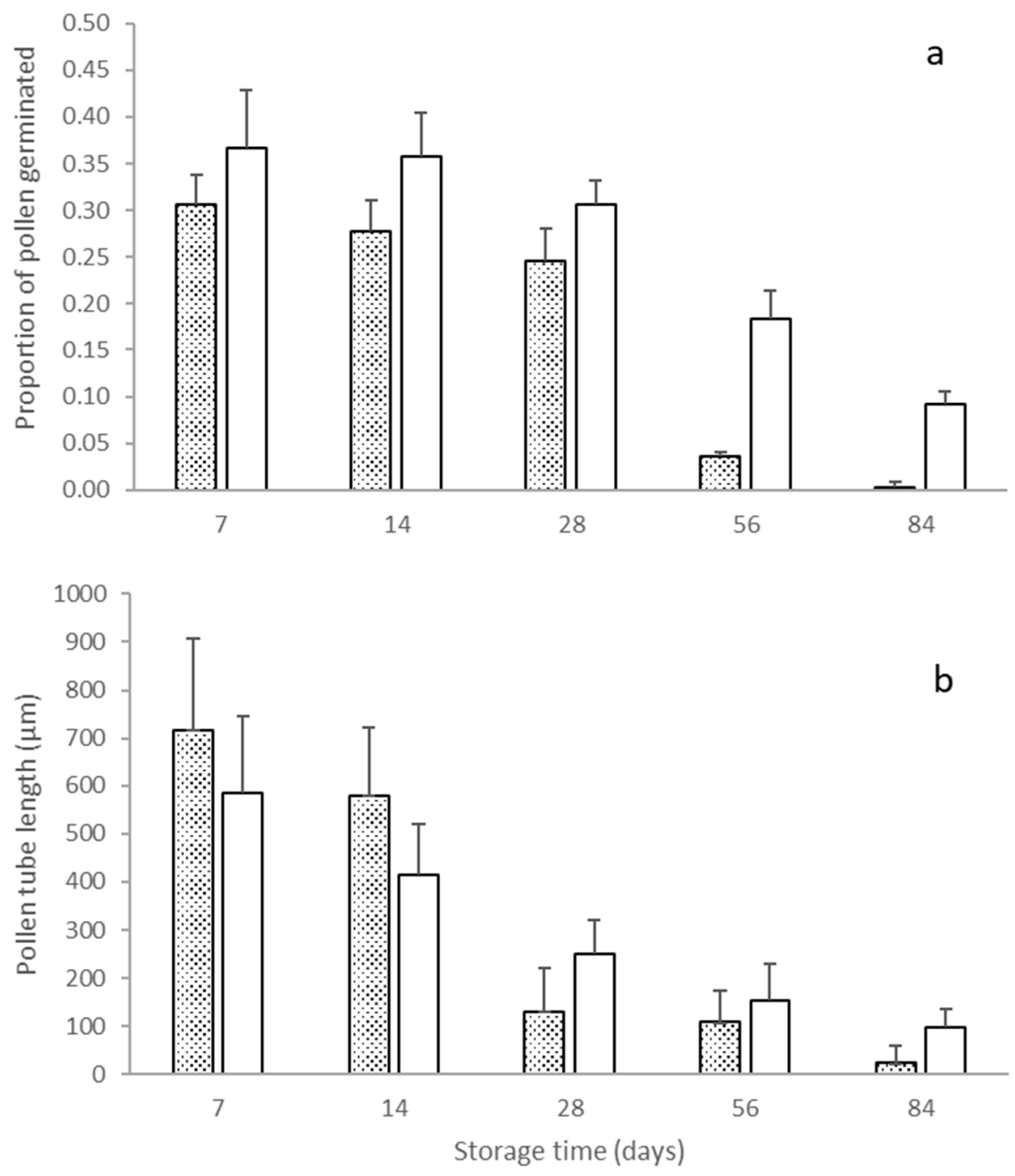

Figure 3. The proportion of pollen grains germinated (a) and the tube length (b) of Gac pollen following storage at $4{ }^{\circ} \mathrm{C}$ and $-20{ }^{\circ} \mathrm{C}$ over time. Values are means $(n=5, \pm \mathrm{SD})$.

\subsection{Physicochemical Properties of Gac Fruits Pollinated with Stored Pollen}

The effect of the pollen storage treatments on fruit properties, compared to the fresh pollen control, considers the factors of storage, temperature (pollen stored at $4{ }^{\circ} \mathrm{C}$ or $\left.-20^{\circ} \mathrm{C}\right)$, storage time $(14,28,56,84$ days) and their interactions. These are summarised and presented in Tables 1 and 2. 
Table 1. Fruit set and some physical characteristics of Gac aril from fruits originally pollinated with fresh and cool-stored pollen. Values are means $(n=3)$ and the significant effects of factors and their interactions are included. The same letters following means within a column are not significantly different. Means are separated when all factors significantly interact. (ns—not significant, temp—-temperature, LSD-least significant difference).

\begin{tabular}{|c|c|c|c|c|c|c|}
\hline Storage Temperature $\left({ }^{\circ} \mathrm{C}\right)$ & $\begin{array}{c}\text { Time } \\
\text { (Days) }\end{array}$ & $\begin{array}{l}\text { Proportion } \\
\text { Fruit Set }\end{array}$ & $\begin{array}{c}\text { Fruit } \\
\text { Weight (g) }\end{array}$ & $\begin{array}{c}\text { Proportion } \\
\text { Aril }\end{array}$ & $\begin{array}{l}\text { Total Seed } \\
\text { Number }\end{array}$ & $\begin{array}{c}\text { Proportion Developed } \\
\text { Seeds }\end{array}$ \\
\hline Fresh pollen & 0 & $0.967 \mathrm{e}$ & 1402.88 & 0.264 & 30.96 & $0.883 \mathrm{~d}$ \\
\hline 4 & 14 & $0.767 \mathrm{~cd}$ & 1173.43 & 0.232 & 30.01 & $0.858 \mathrm{~d}$ \\
\hline 4 & 28 & $0.8 \mathrm{~cd}$ & 1192.60 & 0.234 & 28.50 & $0.844 \mathrm{~cd}$ \\
\hline 4 & 56 & $0.4 \mathrm{~b}$ & 920.45 & 0.225 & 28.58 & $0.57 \mathrm{~b}$ \\
\hline 4 & 84 & $0.1 \mathrm{a}$ & 826.63 & 0.191 & 16.00 & $0.657 \mathrm{bc}$ \\
\hline-20 & 14 & 0.867 de & 1287.28 & 0.237 & 28.59 & $0.804 \mathrm{~cd}$ \\
\hline-20 & 28 & $0.833 \mathrm{~cd}$ & 1251.50 & 0.227 & 29.40 & $0.861 \mathrm{~d}$ \\
\hline-20 & 56 & $0.733 c$ & 1102.07 & 0.231 & 27.80 & $0.799 \mathrm{~cd}$ \\
\hline-20 & 84 & $0.133 \mathrm{a}$ & 908.86 & 0.158 & 21.17 & $0.219 \mathrm{a}$ \\
\hline \multicolumn{7}{|l|}{ Effect: $p$-value (LSD) } \\
\hline Storage & & $\begin{array}{l}<0.001 \\
(0.061)\end{array}$ & $\begin{array}{c}<0.001 \\
(114.22)\end{array}$ & $\begin{array}{c}0.044 \\
(0.046)\end{array}$ & $\begin{array}{c}0.158 \\
(\mathrm{~ns})\end{array}$ & $\begin{array}{c}0.016 \\
(0.144)\end{array}$ \\
\hline Storage*temp & & $\begin{array}{l}<0.001 \\
(0.064)\end{array}$ & $\begin{array}{c}0.007 \\
(120.34)\end{array}$ & $\begin{array}{l}0.62 \\
(\mathrm{~ns})\end{array}$ & $\begin{array}{c}0.654 \\
(\mathrm{~ns})\end{array}$ & $\begin{array}{c}0.195 \\
(\mathrm{~ns})\end{array}$ \\
\hline Storage*time & & $\begin{array}{l}<0.001 \\
(0.07)\end{array}$ & $\begin{array}{c}<0.001 \\
(131.89)\end{array}$ & $\begin{array}{c}0.028 \\
(0.046)\end{array}$ & $\begin{array}{l}0.006 \\
(7.74)\end{array}$ & $\begin{array}{l}<0.001 \\
(0.166)\end{array}$ \\
\hline Storage ${ }^{*}$ time ${ }^{*}$ temp & & $\begin{array}{l}<0.001 \\
(0.081)\end{array}$ & $\begin{array}{c}0.661 \\
\text { (ns) }\end{array}$ & $\begin{array}{l}0.757 \\
(\mathrm{~ns})\end{array}$ & $\begin{array}{c}0.696 \\
\text { (ns) }\end{array}$ & $\begin{array}{l}<0.001 \\
(0.192)\end{array}$ \\
\hline
\end{tabular}

Table 2. Some chemical characteristics of Gac aril from fruits originally pollinated with fresh and cool-stored pollen. Values are means $(n=3)$ and the significant effects of factors and their interactions are included. (TSS-total soluble solids, DW-dry weight, FW—fresh weight, ns—not significant, temp—temperature, LSD-least significant difference).

\begin{tabular}{|c|c|c|c|c|c|}
\hline Storage Temperature $\left({ }^{\circ} \mathrm{C}\right)$ & Time (Days) & TSS ( ${ }^{\circ}$ Brix) & $\begin{array}{c}\text { Oil } \\
\left(\mathrm{g} \mathrm{g}^{-1} \mathrm{DW}\right)\end{array}$ & $\begin{array}{c}\text { Lycopene } \\
\left(\mathrm{mg} \mathrm{g}^{-1} \mathrm{FW}\right)\end{array}$ & $\begin{array}{c}\beta \text {-Carotene } \\
\left(\mathrm{mg} \mathrm{g}^{-1} \mathrm{FW}\right)\end{array}$ \\
\hline Fresh pollen & 0 & 16.18 & 0.29 & 0.373 & 0.24 \\
\hline 4 & 14 & 15.6 & 0.177 & 0.232 & 0.217 \\
\hline 4 & 28 & 15.43 & 0.13 & 0.273 & 0.19 \\
\hline 4 & 56 & 13.37 & 0.127 & 0.38 & 0.297 \\
\hline 4 & 84 & 12.20 & 0.123 & 0.28 & 0.13 \\
\hline-20 & 14 & 15.77 & 0.17 & 0.337 & 0.217 \\
\hline-20 & 28 & 15.37 & 0.207 & 0.343 & 0.26 \\
\hline-20 & 56 & 14.77 & 0.153 & 0.37 & 0.29 \\
\hline-20 & 84 & 12.73 & 0.187 & 0.227 & 0.157 \\
\hline \multicolumn{6}{|l|}{ Effect: $p$-value (LSD) } \\
\hline Storage & & $\begin{array}{l}0.003 \\
(1.09)\end{array}$ & $\begin{array}{l}<0.001 \\
(0.063)\end{array}$ & $\begin{array}{l}0.08 \\
\text { (ns) }\end{array}$ & $\begin{array}{c}0.688 \\
\text { (ns) }\end{array}$ \\
\hline Storage*temp & & $\begin{array}{c}0.158 \\
\text { (ns) }\end{array}$ & $\begin{array}{c}0.062 \\
(\mathrm{~ns})\end{array}$ & $\begin{array}{c}0.891 \\
\text { (ns) }\end{array}$ & $\begin{array}{c}0.509 \\
\text { (ns) }\end{array}$ \\
\hline Storage ${ }^{*}$ time & & $\begin{array}{l}<0.001 \\
(1.26)\end{array}$ & $\begin{array}{c}0.653 \\
(\mathrm{~ns})\end{array}$ & $\begin{array}{c}0.154 \\
\text { (ns) }\end{array}$ & $\begin{array}{c}0.041 \\
(0.121)\end{array}$ \\
\hline Storage ${ }^{*}$ time $e^{*}$ temp & & $\begin{array}{c}0.474 \\
(\mathrm{~ns})\end{array}$ & $\begin{array}{c}0.472 \\
(\mathrm{~ns})\end{array}$ & $\begin{array}{l}0.68 \\
(\mathrm{~ns})\end{array}$ & $\begin{array}{c}0.845 \\
(\mathrm{~ns})\end{array}$ \\
\hline
\end{tabular}

\subsubsection{Physical Properties of Fruit}

Fruit set was significantly affected $(p<0.001)$ by the factors of storage (LSD 0.061), and the interactions storage-temperature (LSD 0.064), storage-time (LSD 0.070) and storagetemperature-time (LSD 0.081). The highest fruit set was achieved with fresh pollen and was most reduced in the longest-stored pollen at both storage temperatures. 
Fruit weight was significantly affected by storage ( $p<0.001$, LSD 114.22), storagetemperature interaction $(p<0.007$, LSD 120.40) and storage-age interaction $(p<0.001$, LSD 131.89). The greatest mean weight was achieved using fresh pollen (1403 g). Fruit originally pollinated with pollen stored at $4{ }^{\circ} \mathrm{C}(1028 \mathrm{~g})$ was significantly reduced compared with pollen stored at $-20^{\circ} \mathrm{C}(1137 \mathrm{~g})$. With each increase in storage time, fruit weight was significantly reduced.

The proportion of fruit as aril was significantly reduced by storage $(p<0.044$, LSD 4.58) but only by pollen stored for the longest time ( 84 days). This reflected a significant storagetime interaction $(p<0.028$, LSD 5.30).

Total seed number per fruit was affected by the storage-time interaction $(p=0.006$, LSD 7.74), but only in fruits pollinated with pollen stored the longest (84 days) were seed numbers reduced. However, the proportion of seeds that were fully developed was affected by storage $(p=0.016$, LSD 14.39), and the interactions storage-time $(p<0.001$, LSD 15.17) and storage-temperature-time ( $p<0.001$, LSD 19.19). Generally, fruits pollinated with pollen stored longer than 56 days at either temperature had proportionally fewer developed seeds.

\subsubsection{Chemical Properties of Aril}

Of the chemical properties of aril, the oil concentration was affected most by the treatments since pollen storage at either temperature reduced the oil concentration compared with fresh pollen $(p<0.001, \mathrm{LSD} 0.06)$. For the other properties, the main negative effect was reductions associated with the longest-stored pollen. Total soluble solids ( ${ }^{\circ}$ Brix) in part reflects the sugar concentration of the aril, and this was affected in fruit by pollen storage ( $p=0.003$, LSD 1.09) and the interaction of pollen storage-time ( $p<0.001$, LSD 1.26). Only the pollen stored at 56 and 84 days significantly reduced TSS in the aril. For the carotenoids, lycopene concentrations in aril were not significantly affected by any factor or interaction of factors, but the $\beta$-carotene concentration was affected by the interaction storage-time ( $p=0.041$, LSD 0.12). Only the fruit pollinated with the oldest pollen had a significantly reduced $\beta$-carotene concentration.

\section{Discussion}

This study highlights how pollination efficiency in Gac production can impact on fruit size and quality. However, it also demonstrates that cold-stored pollen can be used to produce marketable fruit in terms of weight $(>1.2 \mathrm{~kg})$ and aril quality. Reduced pollination efficiency can occur in Gac production when pollen availability is limited or when insect pollinators are limited, or as in the case of this study, when pollen viability is affected by pollen storage conditions. Here, poor pollination success was characterised by reduced fruit set, developed seed set and fruit size at harvest, and some compromised chemical qualities of the aril. These fruit characteristics were most affected by pollen stored at 4 rather than at $-20{ }^{\circ} \mathrm{C}$ and as storage time increased, and strongly reflected the limited germinability of pollen under these storage conditions (Figure 3).

The reduction in fruit weight observed using pollen that had been stored for 14 days at either temperature was not associated with a proportional loss of aril, but nonetheless, reduced the total yield of aril by $12 \%$. Therefore, despite minimal reduction in the concentration of the carotenoids lycopene and $\beta$-carotene as a result of limited pollination, the total yield of these compounds was reduced per fruit associated with the smaller fruit weight. However, in addition to the loss of oil extracted due to reduced fruit size, at least a further $40 \%$ reduction in oil content occurred associated with pollen stored at any time or temperature treatment in the conditions of this study, compared with the fresh control.

A reduction in the oil concentration of aril as a result of poor pollination has additional implications for the nutritional content and value of the fruit. Gac aril is processed to create a range of food and health products, including powders and oil capsules [15], and aril with a reduced oil content would likely compromise the health quality of these processed products. In particular, when eaten, the bioaccessibility of carotenoids depends on the 
presence of lipids, and it has been shown that even when carotenoids are supplemented with oil, they do not compare as favourably to the high bioaccessibility of carotenoids consumed as Gac aril [17]. Despite these limitations, it is worth noting that the maximum levels of lycopene $\left(0.38 \mathrm{~g} \mathrm{~g}^{-1} \mathrm{FW}\right), \beta$-carotene $\left(0.3 \mathrm{~g} \mathrm{~g}^{-1} \mathrm{FW}\right)$ and oil $\left(0.21 \mathrm{~g} \mathrm{~g}^{-1} \mathrm{DW}\right)$ in Gac fruits that were pollinated with cold-stored pollen in this study are within those ranges reported for commercial Gac in the literature (lycopene $0.38-3.73 \mathrm{~g} \mathrm{~g}^{-1} \mathrm{FW}$, $\beta$-carotene 0.08-1.6 $\mathrm{g} \mathrm{g}^{-1} \mathrm{FW}$, and oil $\left.0.17 \mathrm{~g} \mathrm{~g}^{-1} \mathrm{DW}\right)[18,19]$. So, from this perspective, we have been able to at least demonstrate that fruit aril produced from pollination with cold-stored pollen can be of a marketable quality.

It was possible in this study to cold-store pollen and produce a marketable Gac fruit, but it is evident that a protocol for collecting and storing pollen could be developed to better maintain pollen viability and reduce the risk of compromised fruit quality. Previous research has also demonstrated some pollen viability following short-term storage in Gac for up to $30 \mathrm{~h}$ [13], and for other cucurbit pollen including Momordica doica and M. sahyadrica, cryopreserved for $48 \mathrm{~h}$ [20], and in Citrullus lanatus under refrigeration at $4{ }^{\circ} \mathrm{C}$ for up to one week in the organic solvent pentane [21]. However, it is unfortunate that pollen preparations prior to storage in these studies were not described.

Since Gac pollen appears to be desiccation tolerant, also termed orthodox, this provides some direction as to how this pollen may be stored longer-term. Orthodox pollen can be dehydrated to a low moisture content, which lends itself to long-term storage [22], unlike recalcitrant or desiccation sensitive pollens which are shed at higher moisture contents and die rapidly on drying [23]. Pollen from species of Cucurbitaceae can be either orthodox or recalcitrant [23-25]. In this study, Gac pollen took nine days to lose all germinability (Figure 1), and this is characteristically orthodox in contrast to the recalcitrant cucurbit pollen of Cucurbita pepo, which had lost all germinability after only four hours under similar ambient conditions [25].

A suitable moisture content for the storage of Gac pollen could be determined by observing the minimum moisture content obtained during maturation drying of the pollen. The final maturation of orthodox pollen is associated with drying in the anther prior to dehiscence, or once pollen is exposed to the environmental conditions of dispersal, or during dispersal [23]. At collection two hours after anthesis, Gac pollen had presumably undertaken the maturation-dehydration process and was near peak viability since it achieved $97 \%$ fruit set. However, prior to the storage treatments, it appears likely that pollen rehydration occurred to a moisture content above that associated with an inactive state. At this point, the pollen may not have been desiccated enough to solidify the cytoplasm and slow chemical reactions sufficiently to protect the pollen material in dry and cold conditions long-term [26,27]. Thus, research needs to be undertaken to understand Gac pollen maturation and the moisture content at dehydration before storage protocols can be developed.

It is suggested that pollen with desiccation tolerance can be dried to below $5 \%$ moisture content by exposing pollen to humidity below 30\% [28]. However, to achieve the target moisture content, once determined for Gac, further research is required to develop a simple and low-cost protocol suitable for rural areas where it is grown, such as in Vietnam and Thailand. One successful approach, used for pollen conservation of an endangered species (Lapageria rosea) in Chile, compared drying pollen at either $37^{\circ} \mathrm{C}$ in an oven, or dehydration in a desiccator containing granulated silica gel for several defined periods prior to storage in a refrigerator, freezer or at ambient temperature for several months [29]. It determined that oven drying pollen for $15 \mathrm{~min}$ and storage at $-13{ }^{\circ} \mathrm{C}$ achieved $60-65 \%$ germinability for 5 months and paved the way for hand pollination techniques to be developed. A similar approach may be suitable for Gac.

\section{Conclusions}

Few pollination studies consider aspects of fruit quality beyond fruit size or weight, and here we have highlighted that pollen viability and pollination efficiency itself play a role 
in the nutritional value of harvested Gac fruit, a characteristic prized by consumers. Therefore, one priority in developing storage protocols for Gac pollen includes the assessment of aril qualities desired for human nutrition. We have also demonstrated the possibility of using cold-stored pollen to produce fruit with marketable qualities. A further focus for research is the determination of a suitable moisture content for pollen during storage by observing the moisture content of pollen grains in the anther as they undergo dryingmaturation. These findings can be used to develop pollen storage protocols in the context of a commercial farm that needs a reliable supply of fertile pollen for hand pollination.

Author Contributions: Conceptualisation, X.T.T., S.E.P., M.H.N. and P.D.R. Methodology, data collection and original data analysis: X.T.T. Data presentation, writing, reviewing and editing X.T.T. and S.E.P. All authors have read and agreed to the published version of the manuscript.

Funding: This research was funded by the Vietnamese Government and The University of Newcastle, Australia.

Institutional Review Board Statement: Not applicable.

Informed Consent Statement: Not applicable.

Data Availability Statement: Data sets analysed during the current study are available from the current author on reasonable request.

Acknowledgments: The authors would like to thank Lorraine J. Spohr and Ann Harris (NSW Department of Primary Industries) for their assistance with the experimental design and analysis, and Tien Huynh, Department of Applied Science, and School of Science at RMIT University, for her support in the SEM study. We also thank the anonymous reviewers for providing valuable feedback.

Conflicts of Interest: The authors declare no conflict of interest.

\section{References}

1. Telford, I.R. Cucurbitaceae; Australian Government Publishing Service: Canberra, Australia, 1982.

2. Aoki, H.; Kieu, N.T.M.; Kuze, N.; Tomisaka, K.; Chuyen, N.V. Carotenoid pigments in gac fruit (Momordica cochinchinensis Spreng). Biosci. Biotechnol. Biochem. 2002, 66, 2479-2482. [CrossRef] [PubMed]

3. Ishida, B.K.; Turner, C.; Chapman, M.H.; McKeon, T.A. Fatty acid and carotenoid composition of gac (Momordica cochinchinensis Spreng) fruit. J. Agric. Food Chem. 2004, 52, 274-279. [CrossRef] [PubMed]

4. Vuong, T.L. Underutilized $\beta$-carotene-rich crops of Vietnam. Food Nutr. Bull. 2000, 21, 173-181. [CrossRef]

5. Kha, T.C.; Nguyen, M.H.; Roach, P.D.; Parks, S.E.; Stathopoulos, C. Gac fruit: Nutrient and phytochemical composition, and options for processing. Food Rev. Int. 2013, 29, 92-106. [CrossRef]

6. Lopez-Huertas, E. Health effects of oleic acid and long chain omega-3 fatty acids (EPA and DHA) enriched milks. A review of intervention studies. Pharmacol. Res. 2010, 61, 200-207. [CrossRef]

7. Parks, S.E.; Murray, C.T.; Gale, D.L.; Al-Khawaldeh, B.; Spohr, L.J. Propagation and production of gac (Momordica Cochinchinensis Spreng), a greenhouse case study. Exp. Agric. 2013, 49, 234-243. [CrossRef]

8. Tran, T.X. Improving Production and Quality of Gac (Momordica cochinchinensis Spreng) Fruit. Ph.D. Thesis, The University of Newcastle, Ourimbah, Australia, 2017.

9. Pereira, M.C.T.; Crane, J.H.; Montas, W.; Nietsche, S.; Vendrame, W.A. Effects of storage length and flowering stage of pollen influence its viability, fruit set and fruit quality in 'Red' and 'Lessard Thai' sugar apple (Annona squamosa) and 'Gefner' atemoya (A. cherimola $\times$ A. squamosa). Sci. Hortic. 2014, 178, 55-60. [CrossRef]

10. Samnegård, U.; Hambäck, P.A.; Smith, H.G. Pollination treatment affects fruit set and modifies marketable and storable fruit quality of commercial apples. R. Soc. Open Sci. 2019, 6, 190326. [CrossRef]

11. Tran, X.T.; Parks, S.E.; Roach, P.D.; Golding, J.B.; Nguyen, M.H. Effects of maturity on physicochemical properties of gac fruit (Momordica cochinchinensis Spreng). Food Sci. Nutr. 2016, 4, 305-314. [CrossRef]

12. Anusree, T.; Abhina, C.; Lishiba, P.P.; Rasna, T.V.; Varma, S.; Sinu, P.A. Flower sex expression in cucurbit crops of Kerala: Implications for pollination and fruitset. Curr. Sci. 2015, 109, 2299-2302. [CrossRef]

13. Maharana, T.; Sahoo, P.C. Floral biology of Momordica species. J. Hortic. For. 1995, 4, 143-151.

14. Hong, T.D.; Ellis, R.H.; Buitink, J.; Walters, C.; Hoekstra, F.A.; Crane, J. A model of the effect of temperature and moisture on pollen longevity in air dry storage environments. Ann. Bot. 1999, 83, 167-173. [CrossRef]

15. Kha, T.C.; Nguyen, M.H.; Roach, P.D.; Stathopoulos, C.E. Effects of gac aril microwave processing conditions on oil extraction efficiency, and $\beta$ carotene and lycopene contents. J. Food Eng. 2013, 117, 486-491. [CrossRef]

16. VSN International. Genstat for Windows, 21st ed.; VSN International: Hemel Hempstead, UK, 2020. 
17. Müller-Maatsch, J.; Sprenger, J.; Hempel, J.; Kreiser, F.; Carle, R.; Schweiggert, R.M. Carotenoids from gac fruit aril (Momordica cochinchinensis [Lour.] Spreng) are more bioaccessible than those from carrot root and tomato fruit. Food Res. Int. 2017, 99, 928-935. [CrossRef] [PubMed]

18. Chuyen, H.V.; Nguyen, M.H.; Roach, P.D.; Golding, J.B.; Parks, S.E. Gac fruit (Momordica cochinchinensis Spreng): A rich source of bioactive compounds and its potential health benefits. Int. J. Food Sci. Technol. 2015, 50, 567-577. [CrossRef]

19. Mai, H.C.; Truong, V.; Debaste, F. Optimization of enzyme-aided extraction of oil rich in carotenoids from gac fruit (Momordica cochinchinensis Spreng). Food Technol. Biotech. 2013, 51, 488-499.

20. Khan, M.F.; Abutaha, N.; Nasr, F.A.; Alqahtani, A.S.; Noman, O.M.; Wadaan, M.A.M. Bitter gourd (Momordica charantia) possess developmental toxicity as revealed by screening the seeds and fruit extracts in zebrafish embryos. BMC Complement. Altern. Med. 2019, 184, 19. [CrossRef]

21. Kwon, S.W.; Jaskani, M.J.; Ko, B.R.; Cho, J.L. Collection, germination and storage of watermelon (Citrullus lanatus Thunb) pollen for pollination under temperate conditions. Asian J. Plant Sci. 2005, 4, 44-49. [CrossRef]

22. Connor, K.; Towill, L. Pollen-handling protocol and hydration/dehydration characteristics of pollen for application to long-term storage. Euphytica 2004, 68, 77-84. [CrossRef]

23. Franchi, G.G.; Piotto, B.; Nepi, M.; Baskin, C.C.; Baskin, J.M.; Pacini, E. Pollen and seed desiccation tolerance in relation to degree of developmental arrest, dispersal, and survival. J. Exp. Bot. 2011, 62, 5267-5281. [CrossRef]

24. Carrizo García, C.; Guarnieri, M.; Pacini, E. Carbohydrate metabolism before and after dehiscence in the recalcitrant pollen of pumpkin (Cucurbita pepo L.). Plant Biol. 2015, 17, 734-739. [CrossRef] [PubMed]

25. Nepi, M.; Cresti, L.; Guarnieri, M.; Pacini, E. Effect of relative humidity on water content, viability and carbohydrate profile of Petunia hybrida and Cucurbita pepo pollen. Plant Syst. Evol. 2010, 284, 57-64. [CrossRef]

26. Ballesteros, D.; Pritchard, H.W.; Walters, C. Dry architecture: Towards the understanding of the variation of longevity in desiccation-tolerant germplasm. Seed Sci. Res. 2020, 30, 142-155. [CrossRef]

27. Pacini, E.; Dolferus, R. Pollen developmental arrest: Maintaining pollen fertility in a world with a changing climate. Front. Plant Sci. 2019, 10, 679. [CrossRef] [PubMed]

28. Hoekstra, F.A. Collecting pollen for genetic resources conservation. In Collecting Plant Genetic Diversity: Technical Guidelines; CAB InternationalPublisher: Wallingford, Oxon, UK, 1995; pp. 527-550.

29. Cruzatty, L.C.G.; Droppelmann, F.; Izaguirre-Mayoral, M.L. New protocol for storage of viable pollen of Lapageria rosea (Philesiaceae), an endangered plant species endemic to temperate forests of Chile. Plant Species Biol. 2020, 35, 332-337. [CrossRef] 